\title{
Pembelajaran problem based learning (PBL) untuk meningkatkan pemahaman konsep matriks siswa kelas $\mathrm{X}$ SMKN 2 Singosari
}

\author{
Dian Maya Indrawati, Edy Bambang Irawan* \\ Universitas Negeri Malang, Jl. Semarang No. 5 Malang, Jawa Timur, Indonesia \\ *Penulis korespondensi, Surel: edy.bambang.fmipa@um.ac.id
}

Paper received: 01-11-2021; revised: 15-11-2021; accepted: 30-11-2021

\begin{abstract}
Abstrak
Tujuan penelitian ini untuk mendeskripsikan pembelajaran Problem Based Learning (PBL) yang dapat meningkatkan pemahaman konsep matriks siswa kelas X SMKN 2 Singosari. Objek penelitian adalah siswa kelas X-RPL 1 di SMKN 2 Singosari semester gasal Tahun ajaran 2013/2014 dengan jumlah 33 siswa. Penelitian ini menggunakan pendekatan penelitian tindakan kelas (PTK) dan jenis penelitian yang digunakan menurut model yang dikembangkan oleh Kemmis \& Taggart. Pembelajaran PBL dapat meningkatkan pemahaman konsep matriks siswa kelas X SMKN 2 Singosari melalui tahapan sebagai berikut: (1) orientasi siswa pada masalah, (2) mengorganisasi siswa untuk belajar, (3) membimbing pengalaman individual/kelompok, (4) mengembangkan dan menyajikan hasil karya, dan (5) menganalisis dan mengevaluasi proses pemecahan.
\end{abstract}

Kata kunci: Problem Based Learning; pemahaman konsep matriks

\section{Pendahuluan}

Salah satu tujuan pembelajaran matematika Sekolah Menengah Kejuruan (SMK) menurut Undang-Undang No. 22 Tahun 2003 tentang standart isi adalah memahami konsep matematika. Oleh karena itu, pemahaman konsep sangat penting diajarkan dalam pembelajaran matematika. Namun pada umumnya pembelajaran pada matematika di sekolah saat ini cenderung terfokus pada buku ajar yang digunakan oleh guru dan beorientasi pada materi soal-soal yang ada di buku. Hal ini menjadikan siswa hanya terfokus pada materi yang diajarkan pada buku, bukan pemahaman terhadap materi yang diajarkan. Menurut Nuralam (2001) banyak siswa yang cenderung menghafal konsep-konsep matematika dan menyebutkan definisi yang diberikan guru atau tertera dalam buku teks secara berulangulang tanpa memahami makna konsep dan definisi itu.

Berdasarkan hasil observasi awal yang dilakukan peneliti terhadap kegiatan pembelajaran kelas X- Rekayasa Perangkat Lunak (RPL) 1 SMKN 2 Singosari diperoleh bahwa guru masih mempunyai peranan yang dominan dalam proses pembelajaran. Kegiatan pembelajaran yang dilakukan guru dimulai dari menjelaskan materi secara rinci, kemudian siswa diminta untuk mencatat materi tersebut dan selanjutnya guru meminta siswa untuk mengerjakan latihan soal pada buku tugas masing-masing. Selain itu juga pemahaman konsep siswa terhadap matematika masih cenderung kurang. Hal ini diperoleh dari hasil tes awal yang dilakukan peneliti pada materi PLDV dan SPLDV dimana hanya sekitar 39\% dari 31 siswa yang mengikuti tes memenuhi SKBM yang ditetapkan sekolah yaitu 75 .

Salah satu Salah satu pembelajaran yang dapat dilakukan untuk meningkatkan pemahaman konsep matematika adalah dengan menerapkan pembelajaran Problem Based Learning (PBL). Pembelajaran Problem Based Learning (PBL) merupakan suatu model pembelajaran yang didasarkan pada banyaknya permasalahan autentik yang membutuhkan penyelidikan (Trianto: 2009). Menurut Rusman (2012) Problem Based Learning (PBL) 
menuntut aktivitas mental siswa dalam memahami suatu konsep, prinsip dan ketrampilan melalui situasi atau masalah yang disajikan diawal pembelajaran. Lebih lanjut, karakteristik utama dari pembelajaran PBL adalah permasalahan yang diangkat merupakan permasalahan autentik yang tidak terstruktur. Jadi dapat disimpulkan bahwa pembelajaran PBL adalah pembelajaran yang menjadikan permasalahan autentik sebagai titik awal dari pembelajaran, sehingga dari permasalahan tersebut siswa dapat memahami suatu konsep materi dan menyelesaikan pemecahan masalah berdasarkan permasalahan tersebut. Adapun tahapantahapan pembelajaran PBL menurut Arends (2012) adalah (1) orientasi siswa pada masalah, (2) menggorganisasi siswa untuk belajar, (3) membimbing pengalaman individual/kelompok, (4) mengembangkan dan menyajikan hasil karya, (5) menganalisis dan mengevaluasi proses pemecahan masalah. Berdasarkan latar belakang masalah, dapat dirumuskan masalah sebagai berikut: bagaimanakah pembelajaran Problem Based Learning (PBL) yang dapat meningkatkan pemahaman konsep matriks siswa kelas X SMKN 2 Singosari?.

\section{Metode}

Pendekatan yang digunakan pada penelitian ini adalah penelitian tindakan kelas (PTK). PTK adalah suatu penelitian reflektif yang dilakukan oleh guru untuk memperbaiki praktik mengajar (seperti pengembangan sekolah, PBM, prestasi belajar, keahlian mengajar, dan teknik/metode mengajar) yang dilakukan secara kalaboratif dengan sesamanya, terkait dengan permasalahan sesungguhnya dalam melaksanakan PBM sehari-hari yang dialami guru bersifat reflektif partisipasif, kalaboratif, berulang secara spiral, bersifat kontekstual, dan untuk perbaikan pembelajaran dan hasil pembelajaran (Fatchan, 2009). Sedangkan jenis penelitiannya adalah jenis PTK yang dikembangkan menurut model Kemmis \& Taggart. Ada empat tahapan pada penelitian ini yaitu (1) perencanaan, (2) pelaksanaan tindakan, (3) pengamatan, (4) refleksi.

Data dan prosedur pengumpulan data yang digunakan pada penelitian ini adalah sebagai berikut: (1) data hasil validasi, data tersebut dieroleh dari validator yaitu dosen jurusan matematika. Data yang divalidasi adalah perangkat pembelajaran dan instrumen penelitian. (2) data lembar observasi kegiatan siswa dan guru, data tersebut diperoleh dari siswa kelas X RPL-1 dan observer yaitu 2 mahasiswa jurusan matematika yang melakukan pengamatan terhadap pembelajaran yang dilakukan peneliti. (3) data hasil tes, data tersebut diperoleh dari tes I dan tes II yaitu tes akhir siklus pada siswa kelas X RPL-1. (4) form catatan lapangan, data tersebut digunakan untuk mencatat kegiatan pembelajaran yang dilakukan oleh peneliti dan siswa yang tidak terekam pada lembar observasi.

Instrumen penelitian merupakan alat yang digunakan untuk mengumpulkan data penelitian sesuai dengan jenis data yang diinginkan, instrumen utama pada penelitian ini adalah peneliti sebagai human instrument. Sedangkan instrumen pendukung yang digunakan diantaranya adalah lembar validasi, lembar observasi kegiatan guru dan siswa, lembar tes, lembar catatan lapangan dan dokumentasi.

Teknik analisis data dilakukan secara kualitatif, yaitu reduksi, paparan data, dan kesimpulan. Sedangkan analisis data pendukung mengukur keberhasilan data dianalisis sebagai berikut: (1) hasil validasi, $X=\frac{\text { Total skor }}{\text { Banyak Indikator }}$, (2) hasil lembar observasi kegiatan guru dan siswa presentase nilai rata-rata $(N R)=\frac{\text { jumlah skor }}{\text { skor maksimal }} \times 100 \%$. Pembelajaran Problem Based Learning (PBL) dikatakan berhasil jika dari data lembar observasi guru dan 
siswa minimal berada pada kategori "baik". (3) hasil tes Nilai tes $=\frac{\text { skor perolehan }}{\text { skor maksimum }} \times 100$ dan ketuntasan peningkatan pemahaman konsep dihitung dengan rumus $N A=\frac{N T 1+N T 2}{2}$ dimana NA: nilai akhir siswa, NT 1: nilai tes 1, dan NT 2 : nilai tes 2. Pemahaman konsep siswa dikatakan meningkat jika data hasil tes menunjukkan bahwa minimal 80\% siswa memperoleh nilai lebih dari atau sama dengan 75 sesuai dengan SKBM.

\section{Hasil dan Pembahasan}

\subsection{Hasil}

Berdasarkan hasil observasi terhadap kegiatan belajar mengajar di SMKN 2 Singosari yang dilakukan pada bulan Oktober 2013, diperoleh sebagai berikut: (a) pembelajaran matematika masih cenderung didominasi oleh guru. Guru menerangkan materi secara jelas dan rinci kemudian siswa diminta mencatat dan diberikan rumus-rumus secara langsung, kemudian guru meminta siswa untuk mengerjakan latihan soal yang ada di buku paket pada buku tugas masing-masing. Apabila belum selesai guru meminta siswa untuk mengerjakan di rumah sebagai PR dan akan dibahas pertemuan berikutnya jika mengalami kesulitan. (b) Siswa cenderung kesulitan saat diminta guru untuk mengerjakan soal yang teknik penyelesaiannya tidak ada di buku. (c) Sebagian siswa terlihat bosan dan tidak aktif pada saat proses kegiatan pembelajaran berlangsung. (d) data tes awal diperoleh hanya sebesar 39\% dari 31 siswa yang mengikuti tes yang memenuhi SKBM sekolah yaitu 75. Dari data tersebut dapat disimpulkan bahwa pemahaman siswa pada pelajaran matematika masih kurang. Oleh karena itu, dibutuhkan suatu pembelajaran yang tepat untuk mengatasi permasalahan tersebut. Salah satu cara yang dapat diterapkan adalah menerapkan pembelajaran Problem Based Learning (PBL).

Langkah-langkah model problem based learning $(P B L)$ adalah sebagai berikut (Arends, 2012).

Tabel 2 Langkah-langkah model problem based learning (PBL)

\begin{tabular}{|c|c|c|}
\hline NO & Indikator & Kegiatan Guru \\
\hline 1 & Orientasi siswa pada masalah & $\begin{array}{l}\text { Menjelaskan tujuan pembelajaran, } \\
\text { menjelaskan logistik yang diperlukan, dan } \\
\text { memotivasi siswa terlibat pada aktivitas } \\
\text { pemecahan masalah }\end{array}$ \\
\hline 2 & $\begin{array}{l}\text { Mengorganisasi siswa untuk } \\
\text { belajar }\end{array}$ & $\begin{array}{l}\text { Membantu siswa mendefinisikan dan } \\
\text { mengorganisasikan tugas belajar yang } \\
\text { berhubungan dengan masalah tersebut }\end{array}$ \\
\hline 3 & $\begin{array}{l}\text { Membimbing pengalaman } \\
\text { individual/ kelompok }\end{array}$ & $\begin{array}{l}\text { Mendorong siswa untuk mengumpulkan } \\
\text { informasi yang sesuai, melaksanakan } \\
\text { eksperimen untuk mendapatkan penjelasan } \\
\text { dan pemecahan masalah }\end{array}$ \\
\hline 4 & $\begin{array}{l}\text { Mengembangkan dan } \\
\text { menyajikan hasil karya }\end{array}$ & $\begin{array}{l}\text { Membantu siswa dalam merencanakan dan } \\
\text { menyiapkan karya yang sesuai seperti } \\
\text { laporan dan membantu mereka untuk } \\
\text { berbagi tugas dengan temannya }\end{array}$ \\
\hline 5 & $\begin{array}{l}\text { Menganalisis dan } \\
\text { mengevaluasi proses } \\
\text { pemecahan masalah }\end{array}$ & $\begin{array}{l}\text { Membantu siswa untuk melakukan refleksi } \\
\text { atau evaluasi terhadap penyelidikan mereka } \\
\text { dan proses yang mereka gunakan. }\end{array}$ \\
\hline
\end{tabular}


Peneliti juga menetapkan indikator pemahaman konsep yang diadopsi dari Sanjaya (2009 yang disesuaikan dengan materi dalam penelitian ini adalah sebagai berikut : (1) siswa dapat menyatakan sebuah konsep dengan menggunakan kata-kata sendiri, (2) siswa dapat mengklasifikasikan jenis objek menurut sifat-sifat tertentu dari suatu konsep, (3) siswa dapat memberikan contoh dan non contoh dari konsep yang telah dipelajari, (4) siswa dapat menyajikan konsep ke dalam bentuk representasi matematika.

Berikut akan disajikan hasil data yang telah dikumpulkan:

\section{Hasil validasi}

\begin{tabular}{clll}
\hline No. & Jenis perangkat dan Instrumen & Validator & \\
& & $\mathbf{v}$ & Kesimpulan \\
\hline 1. & Rencana pelaksanaan pembelajaran & 3,1 & Valid \\
2. & Lembar kegiatan siswa & 2,91 & Valid \\
3. & Lembar observasi kegiatan guru & 2,89 & Valid \\
4. & Lembar observasi kegiatan siswa & 3,2 & Valid \\
5. & Soal tes & 3 & Valid \\
\hline
\end{tabular}

Berdasarkan data hasil validasi pada tabel tersebut dapat disimpulkan bahwa perangkat pembelajaran dan instrumen penelitian adalah valid.

Hasil observasi kegiatan guru

\begin{tabular}{llll}
\hline \multirow{2}{*}{ Pertemuan } & \multicolumn{3}{l}{ Obervasi kegiatan guru } \\
\cline { 2 - 4 } & Observer & Presentase & Kategori keterlaksanaan \\
\hline \multirow{2}{*}{2} & I & 82,7 & Baik \\
\cline { 2 - 4 } & II & 80,7 & Baik \\
\cline { 2 - 4 } & I & 84,6 & Baik \\
\hline \multirow{2}{*}{3} & II & 76,9 & Baik \\
\cline { 2 - 4 } & I & 84,6 & Baik \\
\hline 4 & I & 82,6 & Baik \\
\cline { 2 - 4 } & II & 88,4 & Sangat baik \\
\hline Rata-rata perolehan & & 82,6 & Baik \\
\hline
\end{tabular}

Berdasarkan tabel di atas menunjukkan bahwa aktivitas guru dalam melaksanakan pembelajaran Problem Based Learning menghasilkan presentase rata-rata sebesar 82,8\%. Jadi taraf keberhasilan pembelajaran Problem Based Learning berdasarkan hasil observasi kedua observer dalam kategori "baik", sehingga dari hasil observasi pelaksanaan pembelajaran Problem Based Learning (PBL) dapat disimpulkan bahwa seluruh kegiatan guru dalam proses pembelajaran sudah baik sesuai yang direncanakan dan dalam penelitian ini dapat dikatakan mendukung keberhasilan pembelajaran matematika. 
Hasil observasi kegiatan siswa

\begin{tabular}{llll}
\hline \multirow{2}{*}{ Pertemuan } & \multicolumn{3}{l}{ Obervasi kegiatan siswa } \\
\cline { 2 - 4 } & Observer & Presentase & Kategori keterlaksanaan \\
\hline I & I & 80,3 & Baik \\
\cline { 2 - 4 } & II & 82,1 & Baik \\
\hline 2 & I & 78,5 & Baik \\
\cline { 2 - 4 } & II & 76,7 & Baik \\
\hline 3 & I & 82,1 & Baik \\
\cline { 2 - 4 } & II & 80,3 & Baik \\
\cline { 2 - 4 } 4 & I & 80,3 & Baik \\
\hline Rata-rata perolehan & & 78,5 & Baik \\
\hline
\end{tabular}

Berdasarkan hasil tabel diatas diperoleh data bahwa aktivitas kegiatan siswa selama pembelajaran Problem Based Learning (PBL) menghasilkan rata-rata presentase sebesar 79,8\% dan terletak pada kategori "baik". Jadi dapat disimpulkan bahwa aktivitas siswa dalam pelaksanaan pembelajaran Problem Based Learning (PBL) sudah sesuai dengan pembelajaran yang telah direncanakan.

\section{Hasil tes pemahaman konsep}

\begin{tabular}{lll}
\hline Keterangan & Banyak Siswa & Presentase \\
\hline Tuntas belajar & 27 & $81,8 \%$ \\
\hline & & \\
\hline Tidak tuntas belajar & 6 & $18,2 \%$ \\
\hline
\end{tabular}

Berdasarkan tabel di atas dapat diketahui bahwa siswa yang tuntas belajar ada sebanyak 27 siswa dan siswa yang tidak tuntas belajar 6 sebanyak siswa. Jadi dapat disimpulkan bahwa ketuntasan belajar siswa sudah tuntas.

\section{Pembahasan}

Pembelajaran yang digunakan pada penelitian ini adalah Problem Based Learning untuk meningkatkan pemahaman konsep siswa kelas X SMKN 2 Singosari. Pemahaman konsep matriks siswa terjadi karena pada pembelajaran Problem Based Learning (PBL) siswa dituntut untuk menemukan sendiri dan memahami konsep dengan menggunakan permasalahan nyata yang sering siswa temui dalam kehidupan sehari-hari. Dengan kata lain, pemahaman konsep siswa diperoleh tidak hanya menghafalkan konsep dasar matriks. Selain itu juga, pemahaman konsep siswa ini diperoleh berdasarkan tahapan-tahapan pada pembelajaran Problem Based Learing (PBL) menurut Arends (2012: 411) yang meliputi (1) Orientasi siswa pada masalah (Orient students to the problem), (2) mengorganisasi siswa untuk belajar (organize students for study), (3) membimbing pengalaman individual/kelompok (Assist independent and group investigation), (4) mengembangkan dan menyajikan hasil karya (Develop and present artifacts and exhibits), dan (5) menganalisis dan mengevaluasi proses pemecahan masalah (Analyze and evaluate the problem-solving process).

Tahapan yang pertama dalam pembelajaran $P B L$ adalah orientasi siswa pada masalah. Sebelum memulai mempelajari materi terlebih dahulu siswa melakukan kegiatan apersepsi 
mengingat kembali materi prasyarat yang berhubungan dengan materi yang akan dipelajari yaitu matriks. Pemberian apersepsi tersebut sesuai dengan pernyataan yang dikemukakan oleh Suherman (2001: 25) bahwa dalam matematika terdapat topik atau konsep prasyarat sebagai dasar untuk memahami topik atau konsep selanjutnya. Kegiatan selanjutnya adalah menyampian tujuan pembelajaran, hal ini bertujuan untuk memberikan batasan materi yang akan dipelajari. Selain itu, juga digunakan sebagai pemberian motivasi kepada siswa agar terlibat aktif dalam kegiatan pembelajaran. Keaktifan siswa tersebut dapat dilihat melalui kegiatan diskusi untuk menyelesaikan permasalahan yang ada di LKS. Pada kegiatan diskusi tersebut juga terjadi pertukaran ide antara satu siswa dengan siswa lain, sehingga dapat menambah pengetahuan baru siswa pada kegiatan pembelajaran. Peran guru dalam pembelajaan ini adalah memberikan permasalahan kepada siswa dan memberikan bantuan ketika siswa mengalami kesulitan saat menyelesaikan permasalahan tersebut. Pada tahapan ke-3 yaitu membimbing pengalaman individual/kelompok siswa dituntut untuk menemukan dan memahami konsep berdasarkan permasalahan yang diberikan. Untuk tahapan selanjutnya adalah menyajikan hasil diskusi di depan kelas dengan presentasi perwakilan salah satu kelompok yang ditunjuk oleh guru. Dan tahapan yang terakhir adalah melakukan analisis terhadap hsil diskusi dengan memberikan kesimpulan dari hasil diskusi materi yang telah dipelajari dan melakukan evaluasi dengan memberikan 1 soal kepada siswa.

Penelitian tindakan kelas ini dilakukan dalam satu siklus yang terdiri dari $5 \mathrm{x}$ pertemuan. Dimana 4x pertemuan menggunakan tahapan-tahapan PBL, sedangkan pada pertemuan kelima dilakukan tes akhir siklus. Berdasarkan hasil observasi kegiatan guru selama kegiatan pembelajaran PBL diperoleh rata-rata sebesar 82,8\% sehingga dikategorikan "baik", sedangkan hasil kegiatan siswa diperoleh rata-rata sebesar 79, 8\% dan dikategorikan "baik". Dan hasil dari tes menunjukkan bahwa tes I sebesar 66,6\% dan tes II sebesar 87,8\% dari kedua tes tersebut menunjukkan adanya peningkatan sebesar $21,3 \%$. Untuk mengetahui peningkatan hasil belajar siswa secara klasikal dilakukan perhitungan rata-rata tes I dan tes II, sehingga diperoleh peningkatan secara kalsikal sebesar $81,8 \%$. Berdasarkan hasil yang telah diperoleh maka peneliti tidak melanjutkan ke siklus selanjutnya. Hal ini dikarenakan hasil data sesuai dengan indikator keberhasilan yang telah ditetapkan oleh peneliti.

\section{Simpulan}

\subsection{Kesimpulan}

Berdasarkan hasil penelitian yang telah dilakukan dapat disimpulkan bahwa pembelajaran Problem Based Learning (PBL) dapat meningkatkan pemahaman konsep matriks siswa kelas X SMKN 2 Singosari dengan tahapan-tahapan sebagai berikut:

4.2.1. Orientasi siswa pada masalah. Kegiatan yang dilakukan guru pada tahapan ini adalah memberikan apersepsi sebagai materi prasyarat, menyampaikan tujuan, memberikan motivasi, dan menjelaskan secara singkat mengenai pembelajaran yang digunakan yaitu Problem Based Learning (PBL).

4.2.2. Mengorganisasi siswa untuk belajar. Setelah tahapan pertama dilakukan maka tahapan selanjutnya adalah membentuk kelompok. Pembentukan kelompok dibentuk secara heterogen berdasarkan kemampuan akademik siswa, dimana setiap kelompok terdiri dari 4-5 siswa. Kemudian guru meminta perwakilan kelompok untuk mengambil LKS yang telah disediakan oleh guru. Pada tahapan ini guru juga meminta untuk membaca petunjuk dan memahami permasalahan yang ada pada LKS. 
4.2.3. Membimbing pengalaman individu/kelompok. Tahapan ketiga ini merupakan inti dari pembelajaran Problem Based Learning (PBL). Kegiatan yang dilakukan guru pada tahapan ini adalah membantu siswa mengumpulkan informasi yang ada di LKS, mendorong siswa agar aktif dalam proses pemecahan masalah dan menyelesaikan permasalahan di LKS. Dari tahapan ini siswa dapat memahami konsep matriks berdasarkan permasalahan di LKS. (4) Mengembangkan dan menyajikan hasil karya. Pada tahapan ini guru membantu siswa untuk menyiapkan hasil karya berupa laporan diskusi yang telah dilakukan. Kemudian siswa diminta untuk menyajikan hasil diskusi dalam bentuk presentasi. Pada tahapan ini terjadi pertukaran ide antara kelompok satu dengan kelompok yang lain. (5) Mengevaluasi dan menganalisis pemecahan masalah. Siswa diarahkan untuk menyimpulkan kegiatan pembelajaran yang telah dilakukan dengan menjelaskan materi matriks yang telah dipelajari serta, dilakukan evaluasi untuk mengetahui pemahaman konsep yang diterima oleh siswa.

\subsection{Saran}

4.3.1. Penelitian menggunakan pembelajaran Problem Based Learning (PBL) yang dilaksanakan oleh peneliti hanya terbatas untuk mata pelajaran matematika pada materi matriks, untuk penelitian selanjutnya, peneliti memberikan beberapa saran antara lain:

4.3.2. Dalam melaksanakan segala bentuk pembelajaran dengan menggunakan metode diskusi, hendaknya alokasi waktu dalam pembelajaran harus benar-benar diperhatikan. Hal ini dilakukan agar semua kegiatan yang tercantum dan direncanakan di dalam rencana pembelajaran, akan bisa berjalan dengan lancar dan sesuai dengan rencana awal.

4.3.3. Penelitian ini dilakukan dalam 1 siklus sehingga perbaikan/refleksi dilakukan di akhir setiap pertemuan. Disarankan bagi peneliti selanjutnya untuk melakukan penelitian yang serupa lebih dari 1 siklus agar diketahui perbaikan dalam pembelajaran.

4.3.4. Permasalahan yang diberikan masih kurang mencerminkan karakteristik utama pembelajaran PBL yaitu masalah tidak terstruktur. Disarankan bagi peneliti selanjutnya untuk melakukan perbaikan.

\section{Daftar Rujukan}

Arends, Richard. (2012). Learning to teach 9th edition. New York: McGraw-Hill Companies

Arikunto, Suharsimi, dkk. (2009). Penelitian tindakan kelas. Jakarta: Bumi Aksara.

Arikunto, Suharsimi. (2009). Dasar-dasar Evaluasi Pendidikan. Jakarta: bumi aksara

Departemen Pendidikan Nasional. (2004). Pedoman penulisan karya ilmiah. Malang: UM Press

Fatchan, A. (2009). Metodologi penelitian kualitatif, beserta contoh proposal skripsi (Doctoral dissertation, tesis dan disertasi, Malang: Jenggala Pustaka Utama Universitas Negeri Malang).

Rusman, K., \& Riyana, C. (2012). Pembelajaran Berbasis TIK Mengembangkan Profesionalita Guru. Jakarta: PT. Raja Grafindo Persada.

Suherman, dkk. (2001). Strategi pembelajaran matematika kontemporer. Bandung: JICA. Universitas Pendidikan Indonesia (UPI)

Trianto. (2007). Model-model pembelajaran inovatif berorientasi konstruktivis konsep: konsep, landasan, teristik-praktis dan implementasinya. Jakarta: Prestasi Pustaka. 